\title{
KONTROVERSI HALAL-HARAM ASURANSI SYARIAH
}

\author{
Dodih Suhardih \\ Hukum Ekonomi Syari' ah Universitas Islam Negeri (UIN) Bandung \\ Email: kang.dods71@gmail.com
}

\begin{abstract}
ABSTRAK
Asuransi masih diperdebatkan di antara para ilmuwan bila dilihat dari segi hukum Islam. Para Ahli hukum Islam kontemporer sadar sepenuhnya bahwa, status hukum asuransi belum ditentukan oleh pemikir (ahli) hukum Islam terdahulu. Penerapan Takāful saat ini merupakan hasil perjuangan antara pemahaman hukum Islam dengan realitas yang terjadi. Permasalahan tersebut perlu ditinjau ulang dalam tatanan hukum Islam secara mendalam. Makalah ini bertujuan untuk menawarkan aspek-aspek Syariah dalam penerapan Takāful (Asuransi Syariah), dasar hukum Asuransi Takāful (Asuransi Syariah), pandangan ulama terhadap Takaful (Asuransi Syariah), membandingkan karakteristik Takāful (Asuransi Syariah) dan Asuransi Konvensional, serta analisa penulis tentang halal haram asuransi syariah.
\end{abstract}

Kata kunci: Hukum Islam, Takāful, asuransi syari' ah, asuransi komersial

\begin{abstract}
Insurance is still debated among scientists when viewed in terms of Islamic law. Contemporary Islamic jurists are fully aware that the legal status of insurance has not been determined by previous Islamic law experts (experts). The application of Takāful is now the result of the struggle between understanding Islamic law and the reality that occurs. These problems need to be reviewed in the order of Islamic law in depth. This paper aims to offer Shariah aspects in the application of Takāful (Sharia Insurance), Takāful insurance law (Sharia Insurance), scholars' views on Takaful (Sharia Insurance), compare the characteristics of Takāful (Sharia Insurance) and Conventional Insurance, as well as the author's analysis of Halal insurance for Islamic insurance.
\end{abstract}

Keywords: islamic law, takāful, syari'ah insurance, commercial insurance

\section{Pendahuluan}

Dunia Islam dihadapkan pada situasi yang cemas. Beberapa lembaga hukum dan kepentingan sosio-ekonomi telah tumbuh di Barat selama empat ratus tahun terakhir dan telah melakukan serangan besar terhadap umat Islam, dalam bentuk dan struktur, dimana saat ini bertentangan dengan nilai-nilai dan prinsip-prinsip yang 


\section{Tahkím}

Vol. XIV, No. 2, Desember 2018

disajikan oleh Islam. ${ }^{1}$ Salah satu di antaranya adalah asuransi. Asuransi masih menjadi perdebatan para ulama bila dilihat dalam hukum Islam. ${ }^{2}$ Terutama aspek hukumnya. Karena itu masalah ini perlu dikaji lebih jelas dalam hukum Islam. Para ahli hukum Islam kontemporer sepenuhnya menyadari, bahwa status hukum Asuransi belum ditentukan oleh para pemikir hukum Islam terdahulu (para ahli hukum).

Pemikiran yang berlaku saat ini, merupakan hasil perjuangan antara pemahaman hukum Syariat dengan realitas yang terjadi. Namun, ketika diamati melalui studi lebih mendalam, ditemukan bahwa ada asuransi yang diadopsi oleh para ahli hukum Islam (kontemporer) terutama manajemen asuransi yang berdasarkan prinsipprinsip syariah. ${ }^{3}$

Dalam yurisprudensi Islam klasik masalah asuransi merupakan bentuk implementasi yang tidak diketahui, karena tidak ditemukan status hukumnya dalam kajian fiqh klasik. Namun, studi asuransi dalam perspektif Islam kontemporer pada kenyataannya sudah cukup banyak dilakukan oleh para ahli hukum, baik pakar hukum Islam khususnya maupun ekonom Islam pada umumnya. Asuransi adalah masalah yang relatif baru yang belum ada kejelasan hukumnya. Status hukum di masa pra-Islam, merupakan perdebatan yang terjadi di sekitar hukum asuransi yang tidak dapat dihindari. Beberapa ulama melarang dengan alasan ada unsur riba, judi, mengandung penipuan, eksploitasi, dan lain-lain. ${ }^{4}$

Makalah ini bertujuan untuk mengidentifikasi dasar hukum Takāful, pendapat para ulama tentang asuransi, dan mengeksplorasi secara mendalam tentang aspek syariah untuk asuransi syariah.

\section{Asuransi Syari’ah (Takaful)}

Asuransi bukanlah fenomena baru dalam sejarah peradaban manusia. Asuransi sudah ada sejak zaman Babel di Mesopotamia yang bertujuan untuk melindungi properti pribadi, real estat, komersial dan urusan keluarga. Demikian pula, gagasan dan praktik Takäful bukanlah hal baru seperti yang dipraktekkan selama masa Nabi Muhammad saw dengan adopsi konsep Aqilah. Mulai 1970-an dan dikuatkan pada 1990-an, negara-negara Islam dan negara-negara lain dengan populasi muslim yang signifikan telah mendorong penyediaan layanan keuangan, termasuk asuransi, di bawah prinsip-prinsip Islam. Konsep asuransi Takāful atau Islam pertama kali diperkenalkan

\footnotetext{
${ }^{1}$ Muhammad Muslehuddin, Menggugat Asuransi Modern: Mengajukan Alternatif Baru Dalam Perspektif Hukum Islam (Jakarta: Lintera, 1999), h. v.

${ }^{2}$ Kuat Ismanto, Asuransi Syariah: Tinjauan Asas-Asas Hukum Islam (Yogyakarta: Pustaka Pelajar, 2009), h. 7.

${ }^{3}$ Burhanuddin, Aspek Hukum Lembaga Keuangan Syariah (Yogyakarta: Ilmu, 2010), h. 103.

${ }^{4}$ Abdurrauf, “Asuransi Dalam Pandangan Ulama Fikih Kontemporer," Jurnal Al Iqtishad, Vol. 2, No. 2, Juli 2010, h. 139-58.
} 


\section{Tahblím}

Vol. XIV, No. 2, Desember 2018

di Sudan pada tahun 1979, terinspirasi oleh kebutuhan yang berkembang dari konsumen muslim untuk perlindungan asuransi yang sesuai dengan hukum Islam. ${ }^{5}$

Banyak ulama yang sudah ditantang untuk membahas masalah asuransi ini, berkesimpulan bahwa asuransi bisnis tidak sah. Karena mengandung unsur judi dan riba. Bahkan ada unsur mengambil harta dengan cara terlarang dan membutuhkan halhal yang tidak diharuskan oleh hukum. Sedangkan asuransi koperasi (AtTa'awun) dan asuransi sosial, keduanya diperbolehkan, karena pada dasarnya berasal dari kontribusi sukarela. ${ }^{6}$

Menurut Kabir Hasan, et.al, Takāful (Asuransi Islami) merupakan alternatif terhadap asuransi keuangan konvensional. Peserta akan membayar sejumlah uang tertentu sebagai sumbangan dan sebagian tabungan (akun khusus peserta), dengan nama konsep Tabarru' (sumbangan) yang selanjutnya diberitakan kepada perusahaan asuransi. ${ }^{7}$ Mushtafa Ahmad al-Zarqa 'menyatakan kontrak asuransi adalah sistem tadlâmun dan ta'âwun yang dimaksudkan untuk menutupi kerugian yang disebabkan disebabkan oleh bencana. ${ }^{8}$

Hussen dan Tismanstates berpendapat bahwa asuransi Syari' ah (Takāful) adalah dasar dari prinsip saling membantu (al-Ta'awun). Sedangkan praktik bisnis yang dilakukan oleh sistem konvensional berdasarkan sesuatu yang tidak pasti. Karena itu dilarang berdasarkan prinsip-prinsip Islam. ${ }^{9}$ Dalam tata cara Islam, dengan memberikan keamanan dalam kelompok bersama-sama untuk menghindari kerugian. ${ }^{10}$ Asuransi Islam, Takāful berasal dari sumber asli hukum Islam. Tujuannya adalah sebagai alternatif terhadap praktek asuransi konvensional. ${ }^{11}$ Polis asuransi Syari' ah tidak boleh memuat aspek yang bertentangan dengan prinsip-prinsip Islam. Oleh karena itu, setiap elemen dari suatu kebijakan asuransi syari'ah harus benar-benar didasarkan pada syari'ah. $^{12}$

${ }^{5}$ Sharifuddin, et al., "Konsep Takaful (Asuransi Islam) dan Fungsinya dalam Pembentukan Syarikat Takaful Malaysia; Operator Takaful Pertama di Malaysia," International Journal of Humanities and Social Science Invention, Vol. 5, No. 12, Desember 2016.

${ }^{6}$ Abdullah dan Shalah, Fikih Ekonomi Keuangan Islam (Jakarta: Daarul Haq, 2004), h. 281.

${ }^{7}$ Wakhed Akhter, "Risk Management In Takaful," MPRA Paper, No. 40005 (2007), h. 2.

${ }^{8} \mathrm{Mu}$ afā A mad Al-Zarqā', "Aqd alTa"mīn Wa Mawqif alSharī’ah AlIslāmiyyah Minhu (Mecca, 1968), h. 405

${ }^{9}$ Hussen dan Tisman Mustaq Pasha, "Perbedaan Antara Asuransi Takaful Umum dan Umum: Operasional dan Conceptua," Australian Journal of Business and Management Research 1, no. 8 (2013): 24

10 Kabir Hasan, Introduction to Islamic Banking And Finance: Principles And Practice (England: Pearson, 2013), 292.

${ }^{11}$ Olorogun Ayinde Lukman dan Abdelghani Echchabi, "Persepsi dan Adopsi Asuransi Islam di Malaysia: Sebuah Studi Empiris,” World Applied Sciences Journal 20, no. 13 (2012): 407-15..

12 Mohd. Ma'sum Billah, "Sumber Hukum yang Mempengaruhi Takaful (Asuransi Islam)," International Journal of Islamic Financial Services 2, no. 4 (n.d.): 1-9. 


\section{Tahkím}

Vol. XIV, No. 2, Desember 2018

\section{Dasar Hukum Asuransi Syari’ah (Takāful)}

Islam telah meletakkan dasar-dasar persaudaraan ini lebih tinggi sebagai implisit atau eksplisit dalam Al-Qur'an dan Hadis. ${ }^{13}$ Untuk melindungi properti dan kehidupan karena bencana, yang dijalankan sesuai dengan prinsip-prinsip Islam. Landasan lembaga syariah yang menjadi perumusan hukum hukum secara umum. ${ }^{14} \mathrm{Di}$ antaranya dijelaskan dalam QS al-Maidah: 2

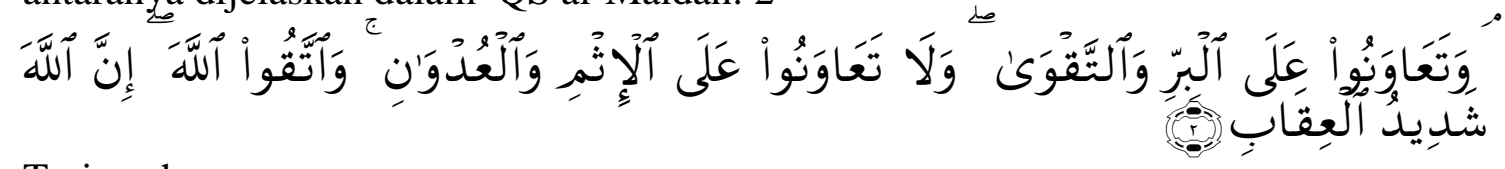

Terjemahnya:

'Dan tolong-menolonglah kamu dalam (mengerjakan) kebajikan dan takwa, dan jangan tolong-menolong dalam berbuat dosa dan permusuhan. Bertakwalah kepada Allah, sungguh Allah sangat berat siksa-Nya. ${ }^{15}$

Ayat ini menganjurkan tolong-menolong dalam kebaikan dan ketakwaan. Salah satu bentuk tolong menolong dalam kebaikan dan ketakwaan adalah bergotong royong menyumbangkan sejumlah dana melalui asuransi, untuk membantu sesama anggota yang membutuhkannya. Begitu juga dijelaskan dalam QS al-Hasyar: 18

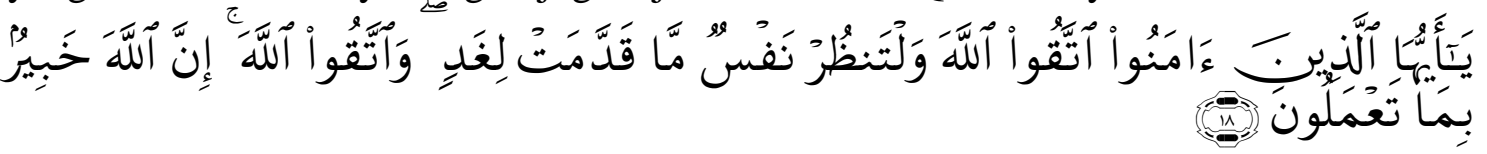

Terjemahnya:

'Wahai orang-orang yang beriman! Bertakwalah kepada Allah dan hendaklah setiap orang memperhatikan apa yang telah dilakukan untuk hari esok (akhirat); dan takut kepada Allah, Sesungguhnya Allah mengetahui apa yang kamu lakukan. ${ }^{16}$

Ungkapan wal tanzhur nafsun ma qadamat lighadin (hendaklah setiap orang memperhatikan apa yang telah dilakukan untuk hari esok) bukan saja berkonotasi untuk hari akherat, tetapi juga berkaitan dengan persiapan terhadap kebutuhan pada hari esok di dunia. Asuransi merupakan salah satu bentuk persiapan untuk mengantisipasi kebutuhan hari esok berupa dana yang telah diserahkan kepada perusahaan asuransi dan dikelola secara syari'at.

Hal senada diisyaratkan dalam QS Yusuf: 46-49

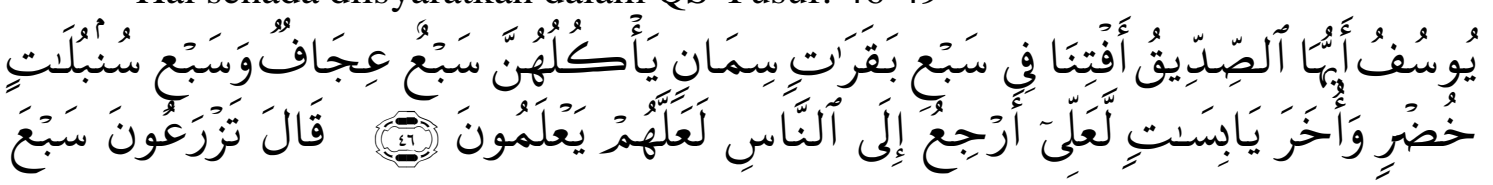

${ }^{13}$ Agus, et al., Solusi Berasuransi: Lebih Indah Dengan Syariah (Bandung: Salamadani, 2009), 16.

${ }^{14}$ Burhanuddin, Aspek Hukum Lembaga Keuangan Syariah

${ }^{15}$ Departemen Agama RI, Al-Qur'an dan Terjemahnya (Jakarta: Ditjen Bimas Islam, 2009), h. 142.

${ }^{16}$ Ibid., h. 799. 


\section{Tahbím}

Vol. XIV, No. 2, Desember 2018

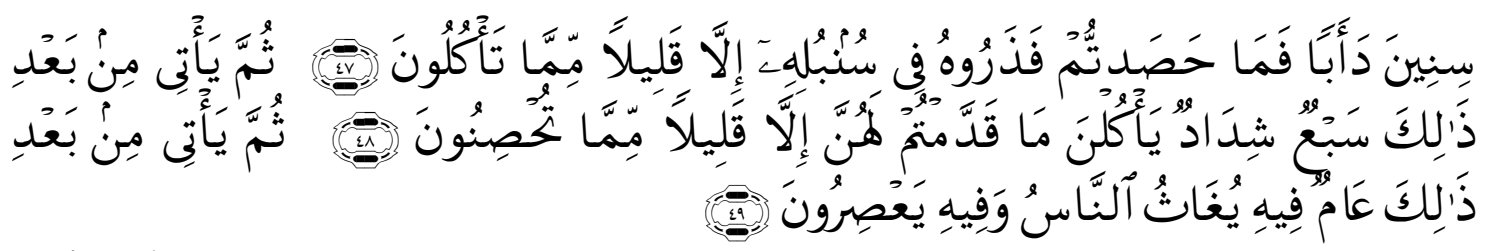

Terjemahnya:

(Setelah pelayan itu bertemu dengan Yusuf dia berteriak): "Yusuf! Jelaskan kepada Kami tentang tujuh ekor sapi betina yang gemuk dimakan oleh tujuh ekor sapi betina yang kurus dan tujuh telinga (gandum) yang hijau dan (tujuh) yang lain kering, agar saya dapat memberitahu kepada orang-orang, sehingga mereka mengetahuinya. "Yusuf berkata:" bahwa kamu bertani tujuh tahun (durasi) seperti biasa; maka apa yang kamu tuai akan kamu tinggalkan dibulirnya kecuali sedikit untuk kamu makan. Kemudian setelah itu akan datang tujuh tahun sangat sulit, yang menghabiskan apa yang Anda simpan untuk menghadapinya (yang sulit), kecuali sedikit (bibit gandum) yang Anda simpan. Kemudian setelah itu akan datang di mana orang diberi hujan (cukup) dan di mana mereka menekan buah anggur.' 17

Di samping itu Sunnah yang berarti jalan yang menjadi kebiasaan dalam melaksanakan ajaran agama atau suatu gambaran amal perbuatan yang sesuai dengan teladan Nabi dan para sahabat, dengan tuntunan al-Qur'an, ${ }^{18}$ juga telah memberikan isyarat tentang asuransi. Di antaranya hadits tentang Aqilah, bahwa:

'Dua orang wanita dari suku Huzail, kemudian salah satu wanita tersebut melempar batu ke wanita yang lain sehingga mengakibatkan kematian wanita tersebut beserta janin yang dikandungnya. Maka ahli waris dari wanita yang meninggal tersebut mengadukan peristiwa tersebut kepada Rasulullah saw. Rasulullah saw memutuskan ganti rugi dari pembunuhan terhadap janin tersebut dengan pembebasan seorang budak laki-laki atau perempuan, dan memutuskan ganti rugi kematian wanita tersebut dengan uang darah (diyat) yang dibayarkan oleh aqilahnya (kerabat dari orang tua laki-laki).' (HR. Bukhari)

Patungan mengumpulkan uang untuk diat dalam kasus ini mirip dengan dana yang dikumpulkan para nasabah asuransi. Begitu juga hadis tentang anjuran menghilangkan kesulitan seseorang. Nabi saw bersabda:

'Barangsiapa yang menghilangkan kesulitan duniawinya seorang mukmin, maka Allah SWT akan menghilangkan kesulitanya pada hari kiamat. Barangsiapa yang mempermudah kesulitan seseorang, maka Allah SWT akan mempermudah urusannya di dunia dan di akhirat.' (HR. Muslim)

Nasabah atau anggota asuransi yang terbantu melalui dana yang dikumpulkan para nasabah sejalan dengan hadis di atas. Demikian juga hadis tentang menghindari risiko.

'Diriwayatkan dari Anas bin Malik ra, bertanya seseorang kepada Rasulullah saw, tentang (untanya): ”Apa (unta) ini saya ikat saja atau langsung saya bertawakal

\footnotetext{
${ }^{17}$ Ibid., h. 324.

${ }^{18}$ https://www.akhmadshare.com/2018/02/dasar-hukum-asuransi-syariah.html
} 


\section{Tahkím}

Vol. XIV, No. 2, Desember 2018

pada Allah swt.“ Bersabda Rasulullah saw: Pertama ikatlah unta itu kemudian bertaqwalah kepada Allah swt.' (HR. at-Tirmizi).

Prinsip asuransi dapat ditelaah juga dari praktik sahabat dalam pembayaran hukuman (ganti rugi) pernah dilaksanakan oleh khalifah kedua yaitu Umar bin Khattab. Beliau berkata: "Orang-orang yang namanya tercantum dalam diwan tersebut berhak menerima bantuan dari satu sama lain dan harus menyumbang untuk pembayaran hukuman (ganti rugi) atas pembunuhan (tidak sengaja) yang dilakukan oleh salah seorang anggota masyarakat." Umar adalah orang yang pertama kali mengeluarkan perintah untuk menyiapkan daftar tersebut, dan orang yang terdaftar diwajibkan saling menanggung beban.

Ijmak yaitu kesepakatan para mujtahid atas suatu hukum syara' mengenai suatu peristiwa yang terjadi setelah Rasul wafat. Para sahabat telah melakukan ittifaq (kesepakatan) dalam hal aqilah yang dilakukan oleh Umar bin Khattab adanya ijmak atau kesepakatan ini tampak dengan tidak adanya sahabat lain yang menentang pelaksanaan aqilah ini. Aqilah adalah iuran dana yang dilakukan oleh keluarga dari pihak laki-laki (asabah) dari si pembunuh (orang yang menyebabkan kematian secara tidak sewenangwenang).

Dalam hal ini, kelompoklah yang menanggung pembayarannya, karena si pembunuh merupakan anggota dari kelompok tersebut dengan tidak adanya sahabat yang menentang khalifah Umar bisa disimpulkan bahwa terdapat ijma dikalangan sahabat Nabi saw mengenai persoalan ini.

Qiyas adalah metode ijtihad dengan jalan menyamakan hukum suatu hal yang tidak terdapat ketentuannya di dalam al-Qur'an dan as-Sunnah dengan kasus lain yang hukumnya disebut dalam al-Qur'an dan as-Sunnah karena persamaan illat (penyebab atau alasannya).

Dalam kitab Fath Al-Bari, disebutkan bahwa dengan datangnya Islam sistem aqilah diterima oleh Rasulullah saw menjadi bagian dari hukum Islam. Ide pokok dari aqilah adalah suku Arab zaman dulu yang harus siap untuk melakukan kontribusi finansial atas nama si pembunuh, untuk membayar ahli waris korban kesiapan untuk membayar kontribusi keuangan ini sama dengan pembayaran premi ide praktik asuransi syariah ini.

Dalam hal ini praktik yang mempunyai nilai sama dengan asuransi adalah praktik aqilah. Aqilah adalah iuran darah yang dilakukan oleh keluarga dari pihak lakilaki si pembunuh.

Istihsan menurut bahasa adalah menganggap baik sesuatu. Menurut istilah menurut ulama ushul adalah beralihnya pemikiran seseorang mujtahid dari tuntutan qiyas yang nyata kepada qiyas yang samar atau dari hukum umum kepada perkecualian karena ada kesalahan pemikiran yang kemudian memenangkan perpindahan 


\section{Tahkím}

Vol. XIV, No. 2, Desember 2018

itu. Seperti halnya kebaikan dari kebiasaan aqilah di kalangan Arab kuno yang terletak pada kenyataan bahwa ia dapat menggantikan balas dendam berdarah.

Muslehuddin mengatakan manfaat signifikasi dari praktik aqilah tersebut adalah:

- Mempertahankan keseimbangan kesukuan dan dengan demikian, kekuatan pembalasan dendam dari setiap suku dapat menghalangi kekejaman anggota suku lain.

- Menambah sebagian besar jaminan sosial, karena mengingat tanggung jawab kolektif untuk membayar ganti rugi, suku harus menjaga seluruh kegiatan anggota sesamanya.

- Mengurangi beban anggota perorangan jika ia diharuskan membayar ganti rugi.

- Menghindarkan dendam darah yang mengakibatkan kehancuran total.

- Mempertahankan sepenuhnya kesatuan darah dan kerjasama para anggota dari setiap suku, yang tak lain merupakan mutualitas (saling membantu).

\section{Perbedaan Asuransi Syari'ah dan Konvensional ${ }^{19}$}

1. Visi dan misi

Asuransi Syariah: aqidah, ibadah (ta'awun), Ekonomi dan perbeedayaan ummat.

Konvensional: Ekonomi dan social.

2. Dewan pengawas

Asuransi Syariah ada dewan pengawasnya sementara konvensional tanpa dewan pengawas.

3. Akad/ perjanjian

Asuransi syariah prinsip tolong menolong, konvensional prinsip jual beli

4. Investasi dana

Asuransi syariah, sesuai dengan perundang-undangan selama sesuai dengan prinsip syariat Islam, bebas dari riba,ghoror, maisir dan bebas dari tempattempat investasi yang dilarang.

Konvensional, bebas melakukan investasi dalam batas perundang-undangan, dan tidak terbatas pada objek investasi tempat-tempat yang halal haramnya atau pada sistem investasi yang digunakan.

5. Kepemilikan dana

Asuransi syariah, dana yang terkumpul dari peserta dalam bentuk iuran (tabarru') yang merupakan milik peserta sementara perusahaan hanya mengelola saja.

\footnotetext{
${ }^{19}$ Muhammad Syakir Sula, Asuransi Syariah (Life \& General) (Jakarta: Gema Insani Press, 2004), h. 326-28.
} 


\section{Tahkím}

Vol. XIV, No. 2, Desember 2018

Konvensional, dana yang terkumpul milik peserta menjadi milik perusahaan dan perusahaan bebas menggunakan dana tersebut.

6. Pengelolaan dana

Asuransi Syariah, ada pemisah dana tabaru, derma dan dana peserta sehingga sehingga tidak mengenal dana hangus kecuali sebaagian kecil saja yang diperuntukan tabaru.

Konvensional, Tidak ada pemisah dana dan pada produk tertentu dana bisa hangus.

7. Penjamin resiko

Asuransi syariah, Sharing of risk yaitu terjadi saling menanggung antara satu peserta dengan peserta lainnya.

Konvensional, Transfer of risk yaitu terjadi resiko dari tertanggung (nasabah) kepada penanggung (perusahaan).

8. Pembayaran Klaim

Asuransi Syariah, diperoleh dari dana tabarru yaitu peserta saling menanggung Konvensional, sumber biaya dari perusahaan yang mana dana ditansfer dari nasabah sebagai resiko nasabah itu sendiri.

\section{Pandangan Ulama tentang Asuransi Syariah (Takāful)}

Asuransi dalam pandangan ajaran Islam termasuk masalah ijtihadiyah, yang berarti bahwa hukum perlu dipelajari sedalam mungkin karena tidak dijelaskan oleh AlQur'an dan Hadis secara eksplisit. Imam-imam mujtahid seperti Abu Hanifah, Imam Malik, Imam Syafe'i, Imam Ahmad Bin Hanbal, tidak memberikan fatwa tentang asuransi.

Akad asuransi modern ditolak oleh ulama atau akademisi Islam dengan berbagai alasan, dan pendukung modernisme Islam menegaskan bahwa asuransi harus berdasarkan hukum Islam. ${ }^{20}$ Ada empat jenis pandangan para ulama tentang asuransi.

1. Semua jenis asuransi, dalam bentuk dan cara beroperasinya adalah haram. ${ }^{21}$

Pandangan itu didukung oleh beberapa ulama, antara lain, Yusuf Al-Qardhowi,

Sayid Sabiq, Abdullah Al-Qalqili, dan Muhammad Bakhit Al-Muth'i. ${ }^{22}$ Dalam pandangan kelompok ulama ini, asuransi dilarang untuk beberapa alasan.

a. Asuransi mengandung unsur perjudian dilarang dalam Islam.

b. Asuransi mengandung unsur ketidakpastian.

c. Asuransi mengandung unsur "Riba" yang dilarang dalam Islam

d. Asuransi mengandung unsur yang menekan eksploitasi.

\footnotetext{
${ }^{20}$ Muhammad Muslehuddin, Menggugat Asuransi Modern: Mengajukan Alternatif Baru Dalam Perspektif Hukum Islam (Jakarta: Lintera, 1999), 145.

${ }^{21}$ Warkum Sumitro, Asas-Asas Perbankan Islam \& Lembaga-Lembaga Terkait (Jakarta: Rajawali Press, 1996), 126.

${ }^{22}$ Warkum Sumitro, Asas-Asas Perbankan Islam \& Lembaga-Lembaga Terkait.
} 


\section{Tahkím}

Vol. XIV, No. 2, Desember 2018

e. Asuransi termasuk penjualan atau pertukaran mata uang tidak dalam bentuk tunai

f. Asuransi merupakan menggantungkan kehidupan sebelum terjadi kematian seseorang, yang berarti mendahului takdir Tuhan.

h. Perusahaan asuransi menginvestasikan uang yang telah dibayarkan oleh tertanggung dalam bentuk jaminan bunga. Dalam asuransi jiwa, jika tertanggung meninggal dunia, ia akan dibayar lebih dari jumlah uang yang ia bayarkan. Ini adalah riba (untung atau bunga).$^{23}$

i. Kelompok ulama yang berpendapat bahwa asuransi sah atau dibolehkan dalam Islam. Pendukung kelompok ulama kedua, antara lain, Abdul Wahab Khallaf, Muh. Yusuf Musa, Abdurrahman Isa, Mustafa Ahmad Zarqa, dan Muhammad Nejatullah Siddiqi.

2. Dalam pandangan kelompok kedua, mempunyai alasan sebagai berikut: ${ }^{24}$

a. Asuransi bukan perjudian, juga bukan judi, karena didasarkan pada kebersamaan dan kerja sama. Perjudian adalah permainan keberuntungan, dan karenanya melemahkan masyarakat. Asuransi adalah anugerah bagi umat manusia, karena ia melindungi mereka dari bahaya yang mengancam kehidupan dan properti mereka dan memberikan manfaat bagi perdagangan dan industri. ${ }^{25}$

b. Tidak ada ketentuan nash, al-Quran dan al-Hadits yang melarang asuransi.

c. Ada kesepakatan kedua belah pihak antara perusahaan asuransi dan tertanggung.

d. Manfaat asuransi lebih dari bahayanya.

e. Termasuk kategori Asuransi kooperatif (Syirkah Taawuniyah) diizinkan dalam Islam.

f. Asuransi adalah kebutuhan dasar manusia karena kecelakaan dan konsekuensi keuangannya membutuhkan kompensasi. ${ }^{26}$

3. Kelompok ulama yang berpendapat bahwa asuransi diperbolehkan untuk sosial tetapi untuk tujuan komersial dilarang dalam Islam. Pandangan ketiga adalah didukung oleh Muhammad Abu Zahroh yang berpendapat bahwa asuransi sosial diperbolehkan karena jenis asuransi sosial ini tidak mengandung unsur yang dilarang dalam Islam.

4. Kelompok ulama yang berpendapat bahwa hukum asuransi, termasuk subhat, karena tidak ada argumen syar'i yang dengan jelas melarang atau yang membenarkan perusahaan asuransi. ${ }^{27}$

\footnotetext{
${ }^{23}$ Muhammad Muslehuddin, Asuransi Dalam Islam.

${ }^{24}$ Warkum Sumitro, Asas-Asas Perbankan Islam \& Lembaga-Lembaga Terkait.

${ }^{25}$ Muhammad Muslehuddin, Asuransi Dalam Islam.

${ }^{26}$ Hendi Suhendi, Fiqh Muamalah (Jakarta: Rajawali Press, 2010).

${ }^{27}$ Warkum Sumitro, Asas-Asas Perbankan Islam \& Lembaga-Lembaga Terkait.
} 


\section{Tahkím}

Vol. XIV, No. 2, Desember 2018

Menurut Dewan Syariah Nasional Majelis Ulama Indonesia (DSN-MUI) dalam fatwanya tentang pedoman umum untuk Takāful. Majelis Ulama Indonesia (MUI) adalah sebuah lembaga yang mengeluarkan fatwa tentang halal dan haram yang menjadi masalah bagi umat Islam di Indonesia. Dewan Syariah Nasional (DSN) adalah dewan yang didirikan oleh MUI untuk menangani isu-isu yang berkaitan dengan kegiatan lembaga keuangan syariah. Takāful dapat ditafsirkan sebagai (ta'mīn, Takāful, ta ämun) yang melindungi upaya bersama dan saling membantu di antara orang atau pihak melalui investasi dalam aset dan/atau tabarru memberi sebuah pola kembali untuk menghadapi risiko tertentu melalui kontrak (pertukaran sesuai dengan syariah). ${ }^{28}$

Fatwa-fatwa Dewan Syariah Nasional (DSN) terkait dengan Asuransi syariah, antara lain:

- Fatwa No: 21/DSN-MUI/X/2001 tentang Pedoman Umum Asuransi Syariah.

- Fatwa No: 51/DSN-MUI/III/2006 tentang Akad Mudharabah, Musyarakah Asuransi Syari'ah.

- Fatwa No. 52/DSN-MUI/III/2006 Tentang Akad Wakalah Bi al-Ujrah pada Asuransi Syariah dan Reasuransi Syariah.

- Fatwa No: 53 / DSN-MUI / III / 2006, tentang Tabarru asuransi syariah.

\section{Analisis Penulis Halal Haram Asuransi Syariah}

1. Asuransi syariah dibolehkan karena belum ada contohnya pada zaman Nabi, baik dalam praktik maupun ucapan. Kaidah ushul fiqh yang digunakan adalah "asal hukum muamalah adalah boleh selama tidak ada dalil yang melarang."

2. Asuransi syariah bebas dari gharar, maisir dan riba'.

3. Dalam asuransi syariah terdapat dua akad, yaitu akad tabarru (hibah) dan akad tijarah (komersial). Dan inilah yang membedakan asuransi syariah dengan konvensional.

4. Namun ada yang mengganjal dalam hati penulis berkenaan dengan dana tabarru' Tabarru' merupakan konsep asuransi syariah dan identik dengan hibah. Akad hibah terjadi pada saat seorang peserta memberikan sejumlah dana untuk dikumpulkan dalam rekening dana tabarru, peserta tersebut berniat untuk menolong para peserta lain, dan pada saat yang sama juga berharap akan mendapat pertolongan apabila dirinya yang mengalami musibah. Apakah ini diperbolehkan? Apa betul dalam asuransi syariah ada aktivitas penarikan dana (tabarru) oleh peserta? Saat kapan, dalam kondisi apa, dan apakah hal itu dibolehkandalam aturan asuransi syariah sendiri? Karena ada Sabda Nabi SAW :

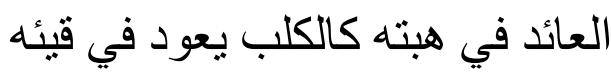

${ }^{28}$ Lihat Fatwa DSN - MUI No.21 / DSN-MUI / X / 2001 tentang takaful 


\section{Tahkím}

Vol. XIV, No. 2, Desember 2018

'Orang yang menarik kembali hibahnya, sama dengan anjing yang menjilat kembali muntahannya.' (HR Bukhari, Muslim, Tirmidzi, Nasa i, Ibnu Majah, dan Ahmad).

\section{Kesimpulan}

Konsep asuransi bukanlah fenomena baru dalam sejarah peradaban manusia. Sudah ada sejak zaman Babel di Mesopotamia yang bertujuan untuk melindungi properti pribadi, real estat, komersial dan urusan keluarga. Demikian pula, gagasan dan praktik Takāful bukanlah hal baru seperti yang dipraktekkan selama masa Nabi Muhammad (SAW) dengan adopsi konsep Aqilah. Mulai 1970-an dan semakin di tahun 1990-an, Konsep asuransi Takäful atau asuransi Islam pertama kali diperkenalkan di Sudan pada tahun 1979, yang terinspirasi oleh kebutuhan yang berkembang dari konsumen Muslim untuk perlindungan asuransi yang sesuai dengan hukum Islam.

Takāful (Asuransi Islam) adalah alternatif dari rencana asuransi keuangan konvensional, dalam rencana Takdir, peserta akan membayar sejumlah uang tertentu sebagai hibah dan sebagian untuk mendanai risiko (akun khusus peserta), dengan konsep Tabarru '(sumbangan) dan dikelola oleh perusahaan asuransi. Landasan syariah menjadi dasar hukum lembaga-lembaga asuransi termasuk dalam quran dan hadits seperti: Qur'an Surat Al-Maidah, ayat: 5, Surat Al-Hashr Ayat 18, Surah Yusuf, Ayat: 46-49, dan HR Muslim.

Ada empat jenis pandangan ulama tentang asuransi. Pertama, semua jenis asuransi, termasuk bentuk dan cara operasi adalah haram. Kedua, sekelompok ulama yang berpendapat bahwa perusahaan asuransi sah atau diizinkan dalam Islam. Ketiga, sekelompok ulama yang berpendapat bahwa diperbolehkan Takāful untuk sosial tetapi asuransi untuk tujuan komersial dilarang dalam Islam. Keempat, Kelompok ulama yang berpendapat bahwa hukum asuransi, termasuk subhat, karena tidak ada argumen syar'i yang jelas-jelas melarang atau yang membenarkan perusahaan asuransi.

\section{DAFTAR PUSTAKA}

Abdullah dan Shalah. Fikih Ekonomi Keuangan Islam, Jakarta: Daarul Haq, 2004.

Abdurrauf. "Asuransi Dalam Pandangan Ulama Fikih Kontemporer," Jurnal Al Iqtishad, Vol. 2, No. 2, Juli 2010.

Agus, et al. Solusi Berasuransi: Lebih Indah Dengan Syariah, Bandung: Salamadani, 2009.

Akhter, Wakhed. "Risk Management In Takaful,” MPRA Paper, No. 40005, 2007.

Ali, Zainuddin. Hukum Asuransi Syariah, Jakarta: Sinar Grafika, 2008 


\section{Tahkím}

Vol. XIV, No. 2, Desember 2018

Anwar, Syamsul. Hukum Perjanjian Syariah: Studi Tentang Teori Akad Dalam Fikih Muamalat. Jakarta: Rajawali Press, 2010

Billah, Mohd. Ma'sum. "Sumber Hukum yang Mempengaruhi Takaful (Asuransi Islam)," International Journal of Islamic Financial Services, Vol. 2, No. 4, t.th.

Burhanuddin. Aspek Hukum Lembaga Keuangan Syariah, Yogyakarta: Ilmu, 2010.

Departemen Agama RI. Al-Quran Dan Terjemahnya, Jakarta: Ditjen Bimas Islam, 2009.

Ghufron, Sofiniyah. Sistem Operasional Asuransi Syariah, Jakarta: Ranaisan, 2005

Hamsa, Amrizal. “Asuransi Dalam Perspektif Islam,” Jurnal at-Tasyri, Vol. 1, No. 2, 2009.

Hendi Suhendi. Fiqh Muamalah. Jakarta: Rajawali Press, 2010

Hussen dan Tisman Mustaq Pasha. "Perbedaan Antara Asuransi Takaful Umum dan Umum: Operasional dan Conceptua," Australian Journal of Business and Management Research, Vol. 1, No. 8, 2013.

Hasan, Kabir. Pengantar Perbankan dan Keuangan Islami: Prinsip dan Praktik, Inggris: Pearson, 2013.

Iqbal, Muhaimin. Asuransi Umum Syariah: Dalam Praktik Menghilangkan Gharar, Maisir, Dan Riba. Jakarta: Gema Insani Press, 2006.

Kuat, Ismanto. Asuransi Syariah: Tinjauan Asas-Asas Hukum Islam Yogyakarta: Pustaka Pelajar, 2009.

Lukman, Olorogun Ayinde, dan Abdelghani Echchabi. "Persepsi dan Adopsi Asuransi Islam di Malaysia: Sebuah Studi Empiris," World Applied Sciences Journal, Vol. 20, No. 13, 2012.

Maulana, Rikza. Perbandingan Sistem Asuransi Syariah Dan Konvensional. Indonesia: Takaful Indonesia, t.th.

Muslehuddin, Muhammad. Asuransi Dalam Islam. Jakarta: Bumi Aksara, 2004.

-------. Menggugat Asuransi Modern: Mengajukan Suatu Alternatif Baru Dalam Perspektif Hukum Islam, Jakarta: Lintera, 1999.

Mutahari, Murtadho. Pandangan Islam Tentang Asuransi Dan Riba, Bandung: Pustaka Hidayah, 1995.

Qardhawi, Yusuf. Daur Al-Qiyam Wa Al-Akhlāq F̄̄ Al- Iqti ād Al-Islām, Cairo: Muassasah al-Risalah, 2002.

Rahman, Fudhail. "Asuransi Dalam Perspektif Hukum Islam,” Jurnal Al'Adalah, Vol. 10, No. 1, 2012.

Sula, Muhammad Syakir. Asuransi Syariah (Life \& General) Jakarta: Gema Insani Press, 2004.

Sharifuddin, et al. "Konsep Takaful (Asuransi Islam) dan Fungsinya dalam Pembentukan Syarikat Takaful Malaysia; Operator Takaful Pertama di 


\section{Tabkim}

Vol. XIV, No. 2, Desember 2018

Malaysia," International Journal of Humanities and Social Science Invention, Vol. 5, No. 12, Desember 2016. 


\section{Tahkím}

Vol. XIV, No. 2, Desember 2018 